Elsevier, Journal of Transport Geography, volume 24, 2012

\title{
Atlanta: A Mega Logistics Center in the Piedmont Atlantic Megaregion (PAM)
}

\author{
Authors \\ Dr. Laetitia Dablanc (corresponding author), IFSTTAR/SPLOTT, 2 rue Butte Verte, Paris- \\ Noisy-le-Grand, 93166, France, Tel. +33 $43 \quad 92 \quad 56 \quad 74$ laetitia.dablanc@ ifsttar.fr, \\ corresponding author \\ Dr. Catherine Ross, Center for Quality Growth and Regional Development, Georgia Institute \\ of Technology, 760 Spring Street, Suite 213, Atlanta, GA, 30308-0790, Tel. +1 404385 5133, \\ catherine.ross@coa.gatech.edu
}

\begin{abstract}
This paper looks at spatial patterns of freight and logistics activities and the planning and policy issues associated with them. Two important characteristics of the geography of the logistics industry are analyzed: (1) "Logistics sprawl," i.e. the spatial deconcentration of logistics facilities and distribution centers in metropolitan areas, and (2) the polarization of logistics activities, i.e. the concentration of logistics activities in very large metropolitan areas. The paper focuses on Atlanta, one of the largest metropolitan areas in the United States (U.S.). Like other very large cities in the U.S., in recent years logistics activities have increased considerably in Atlanta. The paper also examines the Piedmont Atlantic Megaregion (PAM), which has a total population of 15 million and includes Birmingham, Atlanta, Raleigh-Durham and Charlotte. PAM contains many distribution centers with a national and international market area, and is one of the country's fastest growing locations for logistics hubs. The megaregion concept is particularly well-suited to the analysis of freight transport systems, because freight transport's market areas, driven by global supply chains, are largely disconnected from a single city and spatially organized on a regional and multicity basis. Another focus of the paper is the question of planning for a more efficient locational pattern of freight facilities across metropolitan areas and within megaregions. Local governments compete for jobs and activities that generate tax revenues, and logistics has become a significant activity for many U.S. metropolitan areas. The megaregion concept can contribute to a more collaborative regional planning approach.
\end{abstract}

\section{Highlights}

We show: 1) the patterns of spatial deconcentration of logistics facilities in metro Atlanta, 2) the polarization of warehouses in the Piedmont Atlantic Megaregion, 3) local government perspectives on logistics activities and the lack of a regional approach.

\section{Key words}

Logistics sprawl, warehouse geography, megaregions, freight planning, regional planning 


\title{
Atlanta: A Mega Logistics Center in the Piedmont Atlantic Megaregion (PAM)
}

\begin{abstract}
This paper looks at spatial patterns of freight and logistics activities and the planning and policy issues associated with them. Two important characteristics of the geography of the logistics industry are analyzed: (1) "Logistics sprawl," i.e. the spatial deconcentration of logistics facilities and distribution centers in metropolitan areas, and (2) the polarization of logistics activities, i.e. the concentration of logistics activities in very large metropolitan areas. The paper focuses on Atlanta, one of the largest metropolitan areas in the United States (U.S.). Like other very large cities in the U.S., in recent years logistics activities have increased considerably in Atlanta. The paper also examines the Piedmont Atlantic Megaregion (PAM), which has a total population of 15 million and includes Birmingham, Atlanta, Raleigh-Durham and Charlotte. PAM contains many distribution centers with a national and international market area, and is one of the country's fastest growing locations for logistics hubs. The megaregion concept is particularly well-suited to the analysis of freight transport systems, because freight transport's market areas, driven by global supply chains, are largely disconnected from a single city and spatially organized on a regional and multicity basis. Another focus of the paper is the question of planning for a more efficient locational pattern of freight facilities across metropolitan areas and within megaregions. Local governments compete for jobs and activities that generate tax revenues, and logistics has become a significant activity for many U.S. metropolitan areas. The megaregion concept can contribute to a more collaborative regional planning approach.
\end{abstract}

\section{Highlights}

We show: 1) the patterns of spatial deconcentration of logistics facilities in metro Atlanta, 2) the polarization of warehouses in the Piedmont Atlantic Megaregion, 3) local government perspectives on logistics activities and the lack of a regional approach.

\section{Key words}

Logistics sprawl, warehouse geography, megaregions, freight planning, regional planning

\section{Acknowledgements}

This article presents some results of the "MEGAREGION" project made possible by a 20102011 partnership between IFSTTAR, the French Institute of Sciences and Technology for Transport, Development and Networks, and the Georgia Institute of Technology, College of Architecture. "MEGAREGION" also benefited from a grant provided by the French Agency for the Environment (ADEME) and the PREDIT research program.

We would like to thank Hans Williams, a master's student from Georgia Tech's School of City and Regional Planning, for his help in collecting, processing and mapping the geographical data. 
The reviewers of the first version of this article provided extremely useful comments and suggestions. 


\section{INTRODUCTION}

This paper looks at spatial patterns of freight and logistics activities and the planning and policy issues associated with them. We address two of the most important aspects of the geography of the logistics industry. The first is logistics sprawl, i.e. the spatial deconcentration of logistics facilities and distribution centers in metropolitan areas (Dablanc and Rakotonarivo, 2010). Going a step further than the existing literature, we examine the sprawl patterns of freight facilities at a very local level (zip-code). The second aspect we examine is the polarization of logistics activities, i.e. the concentration of logistics activities in very large metropolitan areas at the relative expense of smaller cities and rural areas. This second analysis is conducted at the regional, or more exactly "megaregional" level, as explained below.

Atlanta, one of the largest metropolitan areas in the United States, is the first focus of our analysis. It has a population of five million, with 2.5 million jobs. Like other very large cities in the U.S., particularly those inland (Cidell, 2010), Atlanta has experienced very significant growth in logistics activities in recent years. The number of warehouses in the Atlanta metropolitan area increased by 203\% between 1998 and 2008, further signaling the status of logistics as "a driver of Atlanta's economic development" (Pertierra, 2010).

The paper also looks at the Piedmont Atlantic, Atlanta's surrounding "megaregion." Megaregions are large "networks of connected metropolitan centers and their surrounding areas... spatially and functionally linked through environmental, economic and infrastructure interactions" (Ross, 2009: 1). The concept of the megaregion is well-suited to the analysis of freight transport systems, because freight market areas, driven by the organization of global supply chains, are largely disconnected from a single city. As demonstrated by Ross and Woo (2010), a megaregion consists of different urban clusters interconnected by numerous daily truck flows. Terminals such as regional distribution centers and cross-dock facilities are spatially organized on a regional and multicity basis. The Piedmont Atlantic Megaregion (PAM), in the southeastern United States, is one of the eleven currently identified U.S. megaregions. ${ }^{1}$ It includes Birmingham, Atlanta (the main economic center), Raleigh-Durham and Charlotte, and has a total population of 15 million. Piedmont Atlantic contains many distribution centers with a national and international market area, and is one of the country's fastest growing locations for logistics hubs (Cidell, 2010; Andreoli et al., 2010).

\footnotetext{
${ }^{1}$ http://www.america2050.org/megaregions.html
} 
Another focus of the research is the question of planning for a more efficient locational pattern for freight facilities across metropolitan areas and within megaregions. Local governments compete for jobs and activities that generate tax revenues, and logistics has thus become a significant resource for many U.S. metropolitan areas. The megaregion concept can lead to a more collaborative regional planning approach, encouraging a region's governments to act on a larger scale and develop cooperative planning strategies (Ross, 2009).

The article is in four sections. The first includes a literature survey on the geography of freight and logistics activities in the U.S. In section two, an examination of recent locational patterns for warehouses in Atlanta's metropolitan area identifies a phenomenon of "logistics sprawl." An analysis of the spatial patterns of freight facilities in the Piedmont Atlantic Megaregion illustrates the central role of Atlanta at the relative expense of smaller cities and rural areas. In section three, we describe the response of local governments regarding accommodating logistics activities, and the lack of a common megaregional approach. The conclusion makes recommendations about logistics activities that are particularly directed at local and regional decision-makers.

\section{WHY DO LOCATIONAL PATTERNS OF WAREHOUSES MATTER AND WHAT DOES THE LITERATURE SAY ABOUT THEM?}

The warehousing industry has undergone major restructuring, transforming it into a distribution industry serving major importers (Christopherson and Belzer, 2009) and big box retailers, based on direct access to consumption markets and hub and spoke networks. Starting in the 1980s, the U.S. and many other parts of the world entered a "new distribution economy" (Hesse and Rodrigue, 2004), an economy largely dependent upon efficient and increasingly globalized networks of goods distribution and just-in-time operations. This has led to a reduction in large inventories of intermediate and final products, but also to a concomitant rise in hub distribution centers (Movahedi et al., 2009): global supply chains require more logistics facilities, and the way these facilities are spatially organized has become a key feature of an efficient goods distribution network. The rise and characteristics of today's distribution centers are directly responsible for logistics sprawl and the polarization of freight facilities in large conurbations.

\section{The location of warehouses has become less dependent on transport costs}

The efficiency of goods distribution depends upon the optimal location and sizing of freight terminals rather than directly upon transport costs. Freight transportation costs have decreased dramatically over the last thirty years, and for many industries they have become "trivial" (Glaeser and Kohlhase, 2004). Glaeser and Kohlhase (2004: 204) have calculated that, for more than 80 percent of global shipments, transport costs represent less than 4 percent of total value, and trucking costs have fallen "from 38 cents a ton-mile (in 2001 dollars) to 28 cents a ton-mile in 1999." This is an important change from previous decades. Chinitz (1960) in his famous study on the role of freight transportation in the economic wellbeing of the New York area, emphasized the role of freight in promoting or disadvantaging manufacturing development, taking for granted that freight represents a significant cost. "Improvements in transport technologies, the massive enlargement of infrastructure and falling transport costs, not least thanks to cheap oil, changed the role of transport in the second half of the $20^{\text {th }}$ century (...) putting transport out of consideration in economic geography" (Hall et al., 2006). In the 1980s, Morlok (1988) had already recorded the dispersal of warehousing throughout the United States, as compared to a previous situation where logistics was mostly concentrated in the North East. Obviously, factors such as higher fuel prices, labor shortages, or the pricing of environmental costs of freight transportation could 
well increase transport prices and influence locational decisions for warehouses in the future. Currently, however, low freight costs are prevalent and create what Rodrigue (2004) calls an "increased locational flexibility" for freight and logistics facilities.

\section{What are the new distribution centers and where are they?}

A study by the Equal Employment Opportunity Commission (EEOC, 2004), which looked at the impact of logistics centers on the labor market, identifies modern retail distribution centers as large (over 500,000 square feet) and requiring substantial investments in material handling technology. ${ }^{2}$ Very large distribution centers, or "mega DCs" (Andreoli et al., 2010) have driven the recent growth in warehousing establishments. Between 1998 and 2005, the number of distribution centers with more than 100 employees increased twice as fast as smaller facilities (Andreoli et al., 2010). Another important characteristic is flexibility. New goals, brought about by a refocusing of strategies on green logistics or a reorganization following a merger between retailers or manufacturers, can impact the number of warehouses, their location and internal features.

The most desirable logistics locations in the U.S. today are mostly inland, away from the coasts. Cidell (2010: 371) has confirmed a "move towards inland distribution centers" in the U.S. since the 1980s. This research mapped the number of freight establishments per thousand population in 1986 and 2005, showing an increase everywhere but especially in inland areas. "In the mid-1980s, warehousing and distribution activity was fairly randomly distributed, though somewhat concentrated in the west coast and midwest. By 2005, there is a strong pattern of midwestern distribution centers emerging, plus the Pacific Northwest and Piedmont regions to a lesser extent" (Cidell, 2010: 367). According to Rodrigue (2004: 159), "the development of inland terminals, a strategy pursued by many freight forwarders and port authorities, is creating a process of freight diversion." Atlanta, together with Dallas and Chicago, is one of the largest inland distribution markets in the U.S. (ARC, 2008). The opportunity for good regional and national networking between facilities within a supply chain is a key factor. "Ultimately, the changed geography of warehousing is not just about the restructuring of space within metropolitan areas, it is about the spaces connecting metropolitan, regional and national economies. The proliferation and expansion of warehouses and their predilection for easily accessed suburban sites is being driven by the thickening of long-distance linkages among distant economies" (Bowen, 2008: 386).

\section{Logistics sprawl}

The new distribution centers required by the current organization of supply chains and a consumer-based economy are directly responsible for logistics sprawl, i.e. the tendency for warehouses to move from urban to suburban and exurban areas. Within metropolitan areas, logistics sprawl has been a dominant spatial pattern for many years. Historically, warehouses and freight terminals tended to be close to city centers and rail stations. Today, they need more space and are located as close as possible to highway networks and airports. Woudsma et al. (2008) have shown the importance of accessibility to highway nodes and airports when selecting the location of a logistics facility. Suburban and exurban areas are attractive because of the availability and low cost of land and also because it is possible to connect to a more complex economy of regional and national flows from suburban areas.

\footnotetext{
${ }^{2}$ The best account of the new distribution centers is by Foster (2003), describing a new Walgreens distribution center: "it includes approximately 700,000 square feet of storage plus 14 miles of conveyors and a ten-story automated storage and automated retrieval (AS/RS) system with 48,000 pallet locations. The total construction cost is over $\$ 100$ million dollars. The typical facility employs 300 to 400 people, most hired locally. Walgreens actively seeks non-unionized areas with 30 minute commuting times, reliable electric power, and low tax rates" (quoted in EEOC, 2004).
} 
This generates economies of scale for the logistics industry but has an impact on urban landscapes. Logistics sprawl contributes significantly to the unsustainable nature of large metropolitan areas by generating congestion, $\mathrm{CO}_{2}$ emissions and local atmospheric pollution. These impacts are the result of additional vehicle-miles traveled (VMT) generated by the changing location of freight terminals and the increase in distances traveled by trucks and vans to deliver commodities to urban areas where jobs and households remain concentrated. Dablanc and Rakotonarivo (2010) calculate that cross-dock terminals ${ }^{3}$ for parcel and express transport companies moved an average of 6 miles away from the center of Paris between 1975 and 2008. At the same time, jobs in general had moved only 1.3 miles, meaning that logistics sprawl is much more prevalent than the general sprawl of economic activities in metropolitan areas. They estimated the net increase in annual $\mathrm{CO}_{2}$ emissions resulting from the relocation of facilities serving the Paris region to 16,500 tonnes in 2008 compared with 1974.

The issue of logistics sprawl has recently generated some discussion among scholars, mostly economic geographers. "It is the availability of huge parcels of cheap land that drove the emergence of exurban logistics hot spots at the beginning of this decade" (Christopherson and Belzer, 2009: 212-213). Cidell (2010) shows that in 47 of the 50 large metropolitan areas she surveyed, a "decentralization" of freight activity had happened over the last 20 years (1986-2005), as measured via Gini coefficients. Because data were processed at the county level, however, it was difficult to account for some of the relocation patterns, as central counties can be large and locational changes within counties were not covered in Cidell's studies. Our research addresses this issue by looking at data for Atlanta at the sub-county (zipcode) level.

Bowen (2008) used the County Business Patterns for 1998 and 2005 to show the changing geography of warehousing in the U.S. He confirms that these activities have experienced enormous, largely unnoticed, growth in recent years. "Almost no other industry that employs so many people has grown as fast as the warehousing industry in the past few years" (Bowen, 2008: 383). According to his calculation, the number of jobs in the U.S. warehousing and storage industry rose $384 \%$ between 1998 and 2005 . He shows that the growth in warehousing was more marked in suburban counties than in central and rural counties: central city MSA counties saw an annual growth rate of warehousing establishment of $10.2 \%$, non-MSA counties of $9.3 \%$, other MSA counties of $11.8 \%$. Bowen calculates that accessibility to air and highway transportation networks increasingly influences the location of warehousing establishments, even though other factors also play a role.

Hesse (2004: 171), using two case studies from Germany, concludes that logistics activities favor distant locations for many reasons, some of which are specific to this industry while others apply to many economic sectors: "firms try to get rid of traffic jams, the rigidities of planning requirements, or the power of trade unions." He explains how these changes are embedded in a general transformation of the logistics real estate industry, increasingly dominated by global players organizing national or even larger networks of distribution centers. "Once the spatial scale increases, such commodification of land leads to a certain "abstraction" from the concrete place, in favor of the network structure" (Hesse, 2004: 166).

\section{Freight in megaregions}

Some recent research focuses on the megaregional scale, showing its significance for the understanding of freight flows and the increasing interconnection of facilities. Ross and Woo $(2009,2010)$ identify a very strong relationship between road freight transport (which is mostly regional in any case) and megaregions. Using maps from the New York based

\footnotetext{
${ }^{3}$ Cross-dock facilities are the terminals used in the parcel (less than truck load) and express transport industries.
} 
Regional Planning Association, the authors show how megaregions will "capture" the projected trade volumes with foreign countries. Megaregions, as they contain both urban and suburban environments, have a higher share of road transport (Ross et al., 2009), which significantly adds to severe congestion issues. In the future, this will threaten the country's logistics performance. The authors propose policies to address freight issues, including the development of intermodal hubs and a truck pricing scheme, both of which are appropriate for implementation at the megaregion scale.

In an article entitled "Mega-regions and Freight", Gifford et al., (2011) directly explore the relationships between freight movements and the megaregion scale. Using the Commodity Flow Survey (CFS) and comparing CFS 2000 and CFS 2007, the authors show that freight in megaregions has a higher value per ton and a lower volume of tonnage than in non megaregion areas. Megaregions also have some specific features as regards freight generation: the wholesale trade and publishing industries, for example, are much more prevalent, while the mining industry accounts for a substantial portion of freight tonnage and value in non megaregions. They also show that each megaregion has its own economic specificity. However, the data ${ }^{4}$ used by the authors do not adequately represent the movements of goods generated by consumption activities, which are dominant in metropolitan and megaregion areas. Taking retail and services into account would probably increase the convergences between one megaregion and another regarding freight flows.

Rodrigue (2004) provides a conceptual analysis of what freight flows represent for "mega-urban regions," partially based on the Boston-Washington corridor. He identifies the current best explanation of the "distribution paradigm" in mega-urban regions, composed of a global city, other urban centers, and a major corridor. The global city, called the major "articulation point of a mega urban region," serves as the main interface between global, national and regional systems of accumulation and distribution. According to the author, while it is difficult to define exactly the boundaries of a mega urban region, freight flows could well define them, in the same way as passenger transport flows commonly define metropolitan areas. A mega-urban region is actually a logistically integrated entity where "freight flows are ... derived not only from the location of production and consumption activities, but [also] from the complex web of intermediate activities, such as warehousing and transshipment" (Rodrigue, 2004: 151).

O'Connor (2010) looks at "global city regions" and explores their relationships with logistics activities, in a worldwide comparison. However, the author defines logistics activities on the basis of physical indicators that directly relate to maritime containers and tonnes of air freight, excluding trucking and rail activities (therefore an important part of domestic logistics). Hong Kong, Shanghai and Singapore (followed by Dubai and Los Angeles) have the highest Global Logistics Index (GLI) in this author's database. GLI is "the sum of that city's ports and airports share of all total container movements and all air freight loaded in the data bases used" (O'Connor, 2010: 357). Interestingly, he shows that forty-four global city regions in the world account for fifty-eight percent of the world's sea container movements, and almost half the world's sea freight tonnage (in 2006). Logistics activities are indeed concentrated in major cities.

\footnotetext{
${ }^{4}$ The CFS is done every five years as part of the economic census and includes freight type, origin, destination, values, weight, modes of transportation, distance shipped, and ton-miles. However, it excludes most retail and service industries, exploring mainly the manufacturing, wholesale and mining sectors. Imported products are included in the CFS only at the point where they leave the importer's initial domestic location for shipment to another U.S. location, missing the first leg of imports. This makes it more difficult to understand the origindestination flows of commodities, especially into distribution centers and warehouses from overseas.
} 
As can be seen from the literature, the transformation of freight facilities has been responsible for a growing number of theoretical and empirical studies that have pointed to a surge in the number of suburban distribution centers due to the current needs of the consumeroriented economy. However, the existing studies do not adequately address several important dimensions of the geography of warehousing. These include the multiscalar (especially regional) framework, the very local (infra-county) level, and planning aspects. We shall explore these themes in the following sections.

\section{IDENTIFYING THE SPATIAL PATTERNS OF LOGISTICS FACILITIES IN ATLANTA AND PIEDMONT ATLANTIC}

\section{A method for verifying logistics sprawl in Atlanta: centrographic analyses}

Logistics sprawl is one of the main issues related to the changing geography of warehousing and occurs at the metropolitan scale. Introducing a new scale of analysis to research into the spatial issues associated with freight, we have studied the locational patterns of logistics facilities at the zip-code level, while using an innovative indicator to measure logistics sprawl. The technique we have used is centrography, which is the spatial analysis of geographical data based on descriptive spatial statistics (Isard, 1982). This is well-suited to identifying and quantifying sprawl patterns and providing resources for their cartographic representation. Centrographic analysis consists of finding the weighted geometric center, or barycenter, of a geographic distribution. Once this has been done for each data set, the "directional distribution," or the spatially weighted distance of one standard deviation of the distribution is determined. The directional distribution provides an indication of the decentralization and direction of movement of establishments (an establishment is defined as a facility; a single company can have a number of establishments or sites). The mean distance from the barycenter for each distribution is then determined. This method provides data for a cartographic representation of logistics sprawl.

\section{The changes in the location of warehouses in Atlanta since 1998}

Figure 1 shows the results of a centrographic analysis of the location of warehouses (which fall under the NAICS ${ }^{5}$ code 493) in each of Atlanta's zip code areas between 1998 and 2008. The data were obtained from the U.S. Census Bureau County Business Patterns Survey. ${ }^{6}$ This provides an analysis of the number of establishments in all the counties and zip codes in the United States based on a detailed breakdown of industrial sectors and according to nine employment-size classes.

This analysis is compared with the location of all the establishments (representing all economic sectors) and how this changes over time. The analysis allows us to draw some conclusions about logistics sprawl and "relative logistics sprawl" (see below) in Atlanta. As shown in Figure 1, the number of warehousing establishments increased rapidly between 1998 and 2008, from 132 to 401 (an increase of 203.8 percent.) This increase affected both the number of zip codes with warehousing establishments (which rose from 60 in 1998 to 104 in 2008), and the number of warehousing establishments in each zip code. Spatially, as witnessed by the elongation of the directional distribution, the number of warehousing establishments rose in all directions, and their concentration has increased greatly in the north-east.

\footnotetext{
${ }^{5}$ North American Industry Classification System.

${ }^{6}$ http://www.census.gov/econ/cbp/index.html (last accessed on April 26, 2012).
} 


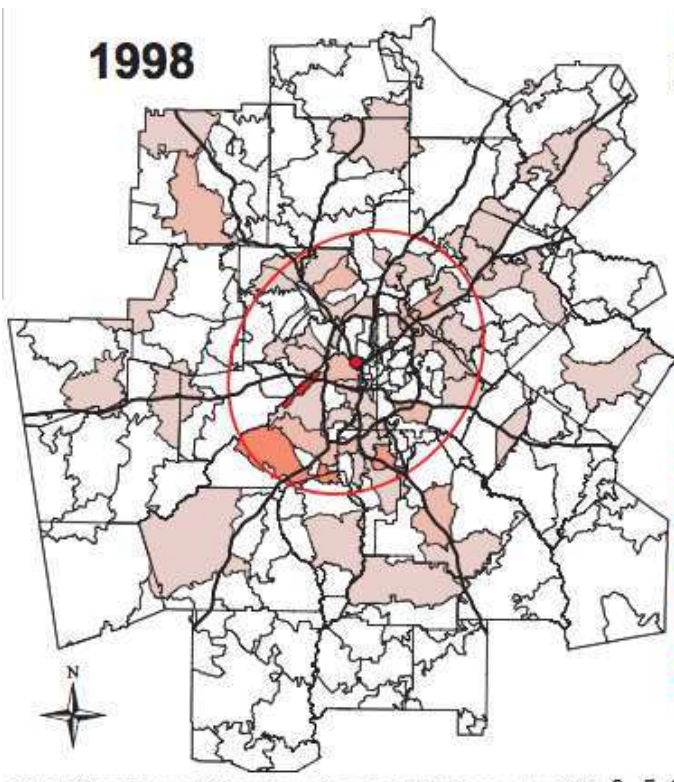

Total Number of Warehousing Establishments: 132 Average Distance from Barycenter 17.8 Miles
Atlanta, Georgia by Zip Code

NAICS: 493100 Warehousing and Storage Number of Warehousing Establishments $\square 0$

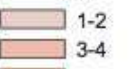

\section{$\square 7-6$}

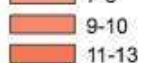

$\square \begin{array}{r}11-13 \\ 14-16\end{array}$

$17-20$

$21-24$

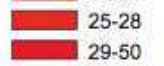

$\square$ Directional Distribution

- Barycenter Expressways Counties

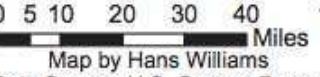
Data Source: U.S. Census Bureau

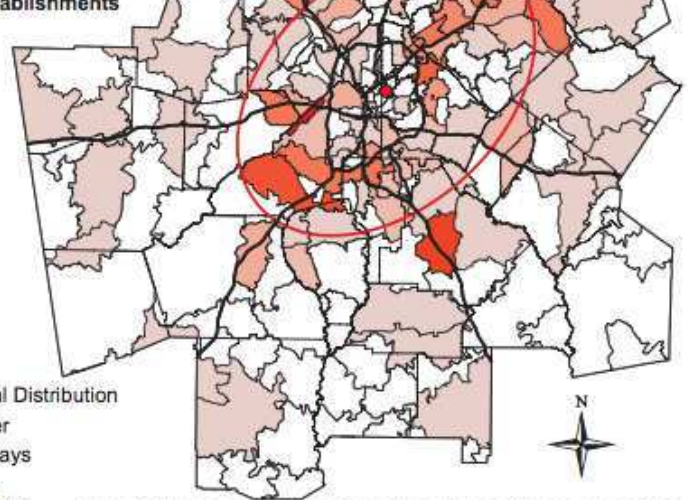

Total Number of Warehousing Establishments: 401 Average Distance from Barycenter 20.6 Miles

FIGURE 1 Centrographic analysis of warehousing establishments, Atlanta, 1998-2008

The situation of logistics establishments was compared with that of all establishments, which represent the final destinations (or the origins) of the goods that are processed in warehouses and distribution centers. The number of establishments of all types in the Atlanta metropolitan area grew much less rapidly than that of warehousing establishments, rising from 330,600 in 1998 to 430,765 in 2008, an increase of $30.3 \%$, compared to $204 \%$ for warehousing establishments. Spatially, establishments became more concentrated in the north during the same period. The barycenter for all establishments moved 1.76 miles to the northeast between 1998 and 2008, compared to 4.2 miles to the east for warehousing establishments. The average distance to the barycenter for all establishments increased by 1.3 miles, from 15.6 miles in 1998 to 16.9 miles in 2008.

This shows that while all establishments in the Atlanta metropolitan area have sprawled (the average distance to their barycenter has increased), warehouses have sprawled more: an average of 2.8 miles in comparison to an average of 1.3 miles. This suggests that within the Atlanta metropolitan area, more truck-miles are required to reach customers (for shipments or deliveries) in 2008 than was the case in 1998. This is "relative sprawl", i.e. when logistics facilities move further away than the businesses they serve for pick-ups and deliveries.

\section{Polarization patterns in the Piedmont Atlantic Megaregion}

Megaregions are very useful geographical scales for the study of freight and logistics, as seen in the first section. Our analysis has focused on the polarization patterns of freight facilities at the megaregional scale. The polarization of logistics activities, also referred to as the "agglomeration" (Gilli, 2009), is the concentration of logistics activities in specific zones. At the urban scale, polarization, as opposed to dispersion, has been identified as a prominent characteristic of logistics facilities (Savy, 2006). Our analysis confirms the existence of logistics polarization at a megaregional scale, in the case of the Piedmont Atlantic 


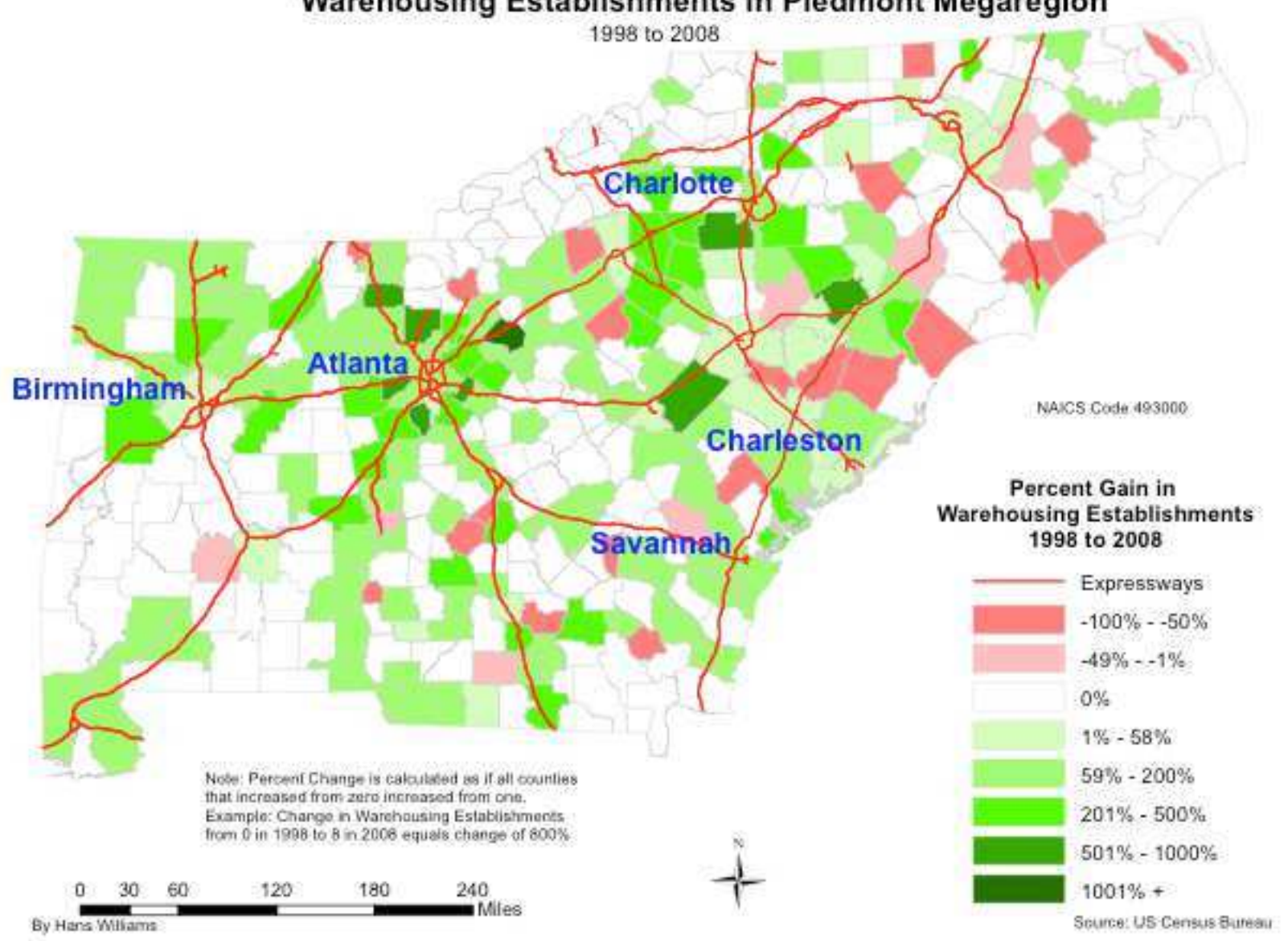

Megaregion. Figure 2 shows the location of warehouses (NAICS 493) in all counties of the PAM between 1998 and 2008. The data are from the County Business Patterns Survey.

FIGURE 2 Warehousing establishments in the Piedmont Atlantic Megaregion, 19982008

Figure 2 shows that the number of warehousing establishments has increased in many counties in the PAM since 1998, especially in or close to the Atlanta metropolitan area. In relative as well as absolute terms, Atlanta's counties have attracted more logistics facilities than most other urban, semi-urban, or rural counties in the region. This is confirmed by the fact that the percentage of South-Eastern ${ }^{7}$ warehouses located in metro Atlanta increased from 13.40 to 18.97 between 1998 and 2008.

\section{LAND-USE PLANNING AND CONTROL OF THE LOCATION OF LOGISTICS FACILITIES}

What account is taken of freight and logistics activities in planning processes? In one of the few academic studies of local planning and freight issues, Cidell (2011: 832) notes the inherent challenges facing local governments confronted with the development of freight facilities: "in a world of flows and networks, [planners] work within bounded territories." Local planners take land use, zoning and permitting decisions based on a "spatial imaginary" founded on a history of the different stages of their municipality's development, from initial

\footnotetext{
${ }^{7}$ Defined as the states of Alabama, Georgia, North Carolina, South Carolina, and Tennessee, approximating the area of influence of the Piedmont Atlantic Megaregion.
} 
rural settlements to fast residential and commercial development. The recent and sudden addition of industrial (mostly logistics) activities to this pattern encounters mixed reactions, mostly unenthusiastic. New jobs are welcome, but the low per-acre tax revenues and absence of sales taxes associated with this type of development are often resented. Looking at how municipalities in Northern California cope with distribution centers, Hesse (2002) also notes a reluctance to attract logistics land uses, even though, according to the surveys he conducted there, most cities do not actually discourage goods distribution firms, even cities with a focus on high technology. He also notes, interestingly, that environmental issues related to freight activities are more inclined to generate relative indifference than much concern.

To explore this further for the case of Atlanta and the PAM, and better identify the ways local planners react to logistics facilities, we shall examine two levels of freight policy, the county and municipal levels, in the Atlanta metropolitan area and then assess freight policies in the whole Piedmont Atlantic Megaregion.

\section{Local government attitudes towards logistics activities}

We conducted interviews with planning managers ${ }^{8}$ in three counties within metro Atlanta: Fulton County, where Atlanta is located; Gwinnett County; and Henry County (Figure 3). The three counties were chosen as they seemed particularly representative of logistics development issues, based on our previous analyses and preliminary interviews with experts and regional practitioners. ${ }^{9}$ The interview findings were presented to and discussed with other experts. ${ }^{10}$

With a population of 920,581 (2010), Fulton County is the Atlanta area's most central and populated county. It currently contains 28 percent of its warehouses and distribution centers (our calculation). One of the main areas where these facilities are located is Fulton Industrial Boulevard (FIB) in the south-west. FIB is one of Atlanta's oldest planned industrial areas. A former county prison farm, it was rezoned and developed by the county into an industrial area in the 1960s and has served as a logistics zone since then. Gwinnett County, in the north-east, contains 22 percent of metro Atlanta's warehouses and distribution centers. In the 1970s, Gwinnett was an agricultural area, but recently has been one of nation's counties with the fastest growing population. Retail activities have also increased rapidly. Henry County in the south-east is much further away from the urban core. Its population has just passed the 200,000 mark (2010), and in the last ten years it has experienced the region's third most rapid population growth. According to Bob White, Executive Director of Henry County Development Authority, large distribution centers represent a sort of natural niche for Henry County, which is home to more than twenty warehousing buildings of over 800,000 sq. $\mathrm{ft}$. This is explained by topography (the county has flat areas and less rocky soils than other parts

\footnotetext{
${ }^{8}$ Randy Beck, Deputy Director, Environmental and Community Development Department, Fulton County, March 25, 2011. Bert Foster, Director, Brian Gardiner, Lead Commercial Inspector, Building Department, Henry County, April 5, 2011. Bob White, Executive Director, Development Authority, April 19, 2011. Bryan Lackey, Acting Director, Planning Department, Gwinnett County, April 18, 2011.

${ }^{9}$ Atlanta Regional Commission: Michael Kray, Freight Program Manager, and Jim Skinner, Principal Planner, Statistics, September 22, 2010, Michael Kray February 23, 2011, Harry West, former Executive Director (19722000), several meetings, Jane Hayes, Head of Transportation Planning, March 9, 2011. Consultancy: Rob Wayson, WilburSmith, January 25, 2011.

${ }^{10}$ City of Atlanta Development Authority: Charles Watley, Director of Business Development, May 27, 2011. MACOC (Metro Atlanta Chamber of Commerce): Bob Pertierra, Vice President, Supply Chain Development, May 6, 2011. Georgia Tech: Nancy Green Leigh, Professor, School of City and Regional Planning, May 17, 2011, Brian Stone, Professor, School of City and Regional Planning, March 2011. Consultancies: David Greene, Perkins and Will, May 27, 2011.
} 
of Atlanta) and above all accessibility: Interstate 75 and seven interchanges are available along twenty miles in the county. In addition, Atlanta's Hartsfield Jackson International Airport is quite close, and the port of Savannah 300 miles away is easily accessed by truck. Land is also cheaper than in many other parts of the region. These counties represent three very different logistics situations and specific attitudes towards logistics activities in the Atlanta area.

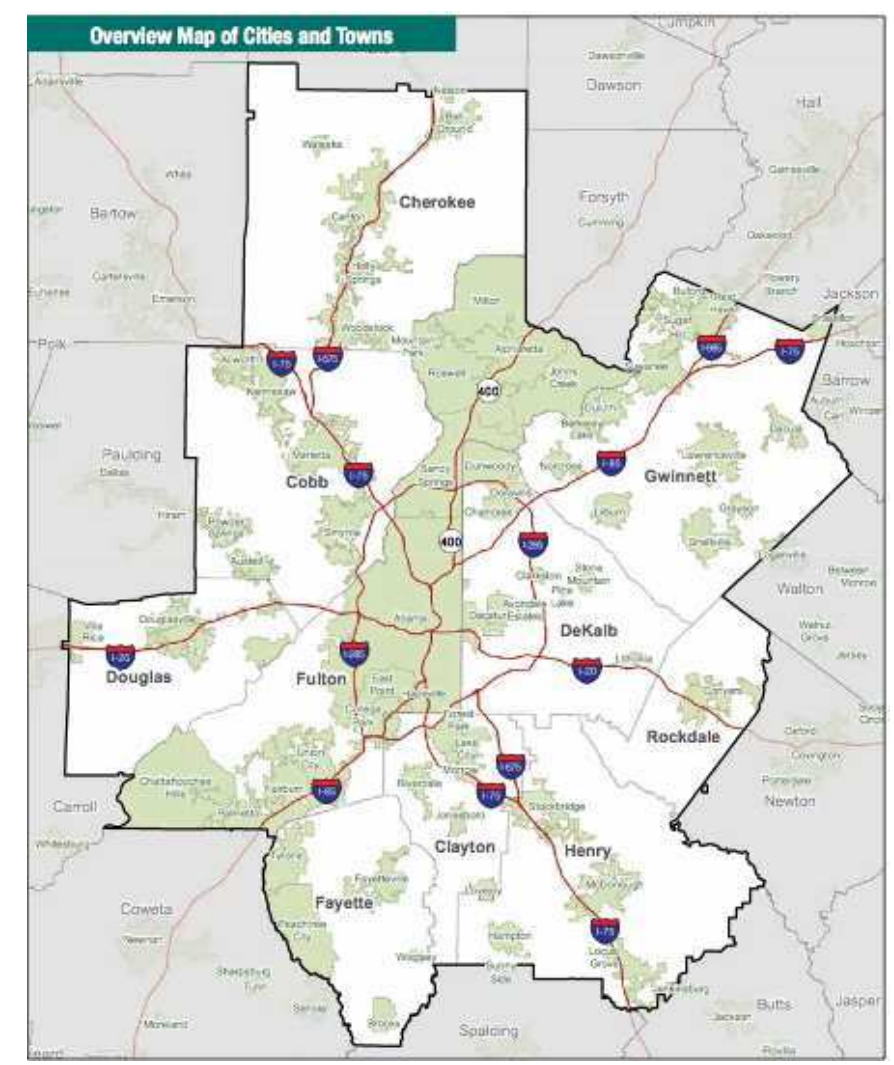

FIGURE 3. Atlanta metropolitan area's governments

Source: Arc (2010: 2)

In the 1980s and 1990s, while remaining an important focus for industrial activities, Fulton Industrial boulevard (FIB) lost some of its attractiveness because of its small and outdated warehouses with low ceilings and small and unwired spaces (Randy Beck interview). Nonetheless, the county is eager to make sure logistics keeps a prominent place in South Fulton's economic development, especially in the FIB area. Today, many warehouses require retrofitting and upgrading, and FIB faces direct competition as newer logistics facilities are being developed in nearby Douglas County. FIB's assets are its central location and low prices. It also has immediate access to two major highways: Interstates 20 and 285. The Charlie Brown local airport for business jets is close-by and access to Atlanta's international airport is also convenient. The southern part of FIB has more recent and modern logistics terminals and better landscaping. A handful of major real estate companies (Avison Young, Millers Logistics, Ackerman and Co, Grubb and Ellis, Pro Logis) own most of the area, and have done an important job in reorganizing land parcels, enlarging them for larger buildings. Because they provide "taxes, growth, and even some sort of prestige when they spill out to the 
local communities, providing jobs for the local people" (Randy Beck interview), warehouses are welcome in Fulton County, at least in industrial areas such as FIB.

The contrary applies in Gwinnett County. The county administration promoted lowrise buildings. "This served us well in the past" (Bryan Lackey) and led to a boom in logistics facilities in addition to major retail developments. But today the strategy is changing. The county wants to attract mixed-use developments, offices and other high-rise buildings, as other northern Atlanta counties have been doing. Urban sprawl is recognized as a major issue, generating traffic congestion and rapidly reducing available land. Higher densities are now considered a valid option for the county's future economic development. Also, logistics facilities are moving eastwards towards Barrow and Jackson counties on Interstate 85 and current logistics facilities in Gwinnett may become vacant. The county's 2030 comprehensive land-use plan emphasizes mixed-use activities, at the expense of industrial areas. The county has therefore chosen to promote a "transition" away from traditional logistics activities towards high-end mixed-use activities.

In Henry County, logistics activities developed only recently, in the 1990s and 2000s and this sector is to be reinforced (Bob White interview). Following commissioners' decisions, new parcels have recently been opened up to industrial development (mostly previously agricultural or forest land), despite some vacancies in existing zones. The new zones are organized as large "parks" or "industrial units" and contain very large distribution centers, many serving companies that trade with Florida. The newly developed logistics areas in Henry County also typify the kind of land speculation that occurred in the first half of the 2000s in logistics real estate. The process is the following: a major company buys a large amount of land, plans and builds the roads and other mandatory amenities then resells parcels to other companies (either direct users or other real estate companies) with a high profit. This was encouraged by the county, eager to promote fast economic development. The county is a "bedroom community" 11 and logistics is considered an essential part of the strategy to provide more local jobs. In this case, local land-use policies directly contributed to the logistics sprawl discussed earlier.

\section{Uncoordinated metropolitan logistics planning}

From our interviews, we identified several issues regarding the way local and regional authorities consider logistics activities in their planning processes.

1. Lack of regional coordination. As many of the decision-makers we interviewed admitted, there is little metropolitan planning of logistics activities in Atlanta. As one county official mentioned, "we love planning but some other counties do not, and are ready to accept anything without any care given to conflicts of use, environmental justice or transitional planning." Some cooperation does exist. Four counties, soon to be joined by Henry County, participate in Atlanta's Joint Development Authority. The objective of this organization is to advertise Atlanta as a place of choice for industry location through trade shows and other promotional activities. "We all work together to get logistics companies to come to our region, then the competition begins among us" (Bob White). Another active cooperation on logistics matters takes place within the Atlanta Regional Commission (ARC). ARC, the metropolitan planning organization of Atlanta, provides regional planning and intergovernmental coordination for a 10-county area including the city of Atlanta. Logistics issues are addressed both in ARC's transportation and land-use committees. However, counties within the region tend to favor individual strategies, and freight and logistics activities remain local matters. In a 2008 report, the ARC (2008: 42) had already warned, with

\footnotetext{
${ }^{11}$ In 2000 , nearly $70 \%$ of the working population of Henry County commuted to another county.
} 
little effect, about un-coordinated planning processes: "As the Atlanta region grows, the demand for reliable and timely freight movement will increase, and cities and counties will experience land use planning challenges associated with this demand."

2. Divergence of policies between the governments of the most urban areas and the rest of the metro area. In central locations, specifically the city of Atlanta, zoning has contributed to the loss of many industrial activities. Industry is excluded from re-development projects, such as at the former Ford plant adjacent to Atlanta international airport, as central cities favor more high tech activities. The city of Atlanta's tax system does not favor warehouses. The inventory tax exemption rate ${ }^{12}$ in the city is lower than in suburban counties (Charles Watley interview), making it difficult for logistics activities to locate in the city. The Atlanta Regional Commission in its 2008 report expressed the concern that logistics facilities may become too distant from the central metropolitan area, leaving truck drivers with longer driving times and delays. Former or current freight uses need to be maintained, with two areas identified as priorities: Fulton Industrial Boulevard, and the military base of Fort Gillem, scheduled for partial closure. (Today - in 2012 -, the ongoing redevelopment of the military base does not include logistics activities). The Metro Atlanta Chamber of Commerce (MACOC) expresses a similar concern: "industrial density should be a major goal of central counties in the Atlanta area" (Bob Pertierra interview).

3. Conflicts between incorporated cities and the rest of the county. These arise when incorporated cities decide their own planning and zoning rules, which can differ from the county's. New parcels can be authorized for industrial and logistics developments by a county, while an incorporated city nearby opposes this type of land use for fear of negative impacts. Annexation, the means by which an existing city extends its corporate boundaries, is a related issue. In Georgia, it is quite difficult for a county to oppose annexation, so it loses activities that generate revenue. In the Atlanta area, some industrial and logistics areas have become targets for annexation, with the risk of reducing county revenues.

4. Internal conflicts. Within a county or municipal government, there are differing views on logistics activities. Different departments find it difficult to identify a common strategy for logistics activities. A department in charge of economic development is generally more favorable to freight and logistics than other departments. While technical staff may try to argue that logistics activities are a valid orientation for future economic development, elected officials are often inclined to promote more attractive activities. Even in areas far from universities and other research resources, high-tech industries such as biotechnology are favored over logistics. The development of office space in lieu of logistics facilities is also a challenging option considering the current amount of vacancies and available land for offices in Atlanta.

Local planners in suburban Atlanta communities were faced with the intrusion of freight and logistics activities at a time when they were used to dealing mostly with residential and retail development. In many instances, logistics was the first industrial activity that these counties and municipalities encountered. This corroborates Cidell's (2011: 833) finding, based on interviews with municipal planners from Will County, south-west of Chicago: "These local municipalities are at the leading edge of the new global logistics network and the leading edge

\footnotetext{
${ }^{12}$ Georgia is one of 14 states in the country that allow for imposition and collection of property tax on business inventories. Exemptions can be provided by local governments (after a referendum) for manufacturer's inventory in process, Georgia manufactured finished products held by the manufacturer, and finished goods awaiting outof-state shipment. Localities may exempt 20 percent, 40 percent, 60 percent, 80 percent, or 100 percent of the value of these types of inventory from taxation (Matthews, 2006).
} 
of suburbanization, making planning decisions based on considerably different kinds of land uses than the traditional single-family housing, commercial strip shopping centers and industrial development." Local governments ${ }^{13}$ in metro Atlanta seem more welcoming to logistics facilities than the municipalities in Chicago examined by Cidell or those in Northern California surveyed by Hesse (2002). Some, such as Henry County, deliberately look for this kind of development. This certainly reflects the long-standing role of freight and transportation in the city's history and the highly visible support they receive from the state of Georgia or institutions such as Atlanta's Chamber of Commerce. The local governments in these three areas (Chicago, Atlanta, and Northern California), however, all welcome logistics jobs, consider that logistics facilities are "cleaner" (Cidell, 2011) than more traditional manufacturing activities, and design zoning codes that address the need for landscape and aesthetic measures for warehouses and distribution centers.

\section{An analysis of freight planning documents in PAM's Metropolitan Planning Organizations (MPOs) and states}

In order to assess the importance that local and state governments in the Piedmont Atlantic Megaregion (PAM) give to freight issues, we analyzed two categories of documents: the long range transportation plans of MPOs and statewide multimodal transportation plans. ${ }^{14}$ Specific freight studies have been included in the analysis. Our main conclusion is that the states and major cities in PAM do not have a significant freight plan despite some recent initiatives (such as in Georgia), and very few of them discuss broader (megaregional) freight issues.

In the Charlotte area, MUMPO's ${ }^{15}$ long range transportation plan of 2010 includes twelve pages on freight, covering all modes from air cargo to road and rail. Freight is recognized as a factor of growth: "Freight handling and transit capacity has become an important platform for regional economic growth." However, the document is very descriptive and few propositions for actual policies are made, with the exception of the implementation of a regional freight forum. In the Birmingham area, ${ }^{16}$ a newly formed Freight Advisory Committee is responsible for a freight planning program that aims to collect data, identify specific freight needs, develop related planning solutions, and reach a regional

\footnotetext{
${ }^{13}$ Metro Atlanta has more counties than many other areas in the U.S. and, with the exception of Fulton County, these do not contain many municipalities (see Figure 3). Our research therefore focuses more on counties (still the deciding entities for logistics land use) than municipalities. This may also account for some differences in attitude towards logistics facilities, as pointed out by one of the reviewers of the first version of this article: counties probably have a longer acquaintance with industrial activities, and more space to accommodate them.

14 The following planning documents were examined for this section. All of them are accessible from the relevant institutions web pages.

Mecklenburg - Union Metropolitan Planning Organization, 2035 Long Range Transportation Plan, adopted March 24, 2010

Capital Area Metropolitan Planning Organization and Durham-Chapel Hill-Carrboro Metropolitan Planning Organization, 2035 Long Range Transportation Plans, adopted March 20, 2009

- Berkeley-Charleston-Dorchester Council of Governments Long Range Transportation Plan, April 2005

Atlanta Regional Commission, Atlanta Regional Freight Mobility Plan Final Report, February 2008

- Atlanta Regional Commission, ASTROMAP: Atlanta Strategic Truck Route Master Plan, 2010

- Alabama Statewide Transportation Plan, June 2008.

- Georgia DOT, 2005-2035 Georgia Statewide Freight Plan, 2007

- South Carolina Statewide Comprehensive Multimodal Transportation Plan, 2008

- Statewide Logistics Plan for North Carolina, An Investigation of the Issues with Recommendations for Action, Final Report, May 13, 2008

${ }_{15}^{15}$ MUMPO: Mecklenburg-Union Metropolitan Planning Organization.

${ }^{16}$ RPCGB: Regional Planning Commission of Greater Birmingham.
} 
consensus on ranking freight projects. The 2035 long range transportation plan of Raleigh's MPO $\left(\mathrm{CAMPO}^{17}\right)$ mentions (p.67) that a commercial vehicle survey is under way, which will include the location of distribution centers throughout the region. Together with the Durham MPO (DCHC ${ }^{18}$ ), a freight plan has been included in a unified planning work program. The Charleston area ${ }^{19}$ takes a wider view of freight: because of the port, "the region serves as a major intermodal link between the south eastern U.S. and the world" (chapter 8.1). Freight is recognized as a major economic asset for the region. The plan then establishes a list of relatively minor freight issues such as the different truck weight restrictions in South Carolina, Georgia and Florida. One metropolitan area which is quite involved in freight is Atlanta. A freight advisory task force was established in 2003 by ARC $^{20}$ and two freight studies have been made in recent years. A Freight Improvement Program costing more than \$75 million has been scheduled for 2014 -2017.

Some recent freight studies have been responsible for reorganizing project ranking processes, seemingly pushing freight projects higher up state agendas. Rail freight is mentioned in several states as an important investment issue. The Alabama Statewide Transportation Plan examines waterways, aviation and airport issues in addition to railways. It defines the state's freight planning efforts as focusing 'on maintaining and improving connections to freight facilities and enhancing the flow of freight throughout the state.' The Alabama DOT launched a freight study and action plan in 2009, and revised its ranking of projects in accordance with the study, taking better account of freight needs. Another outcome of the work was to establish a permanent consultation process with the industry. The state of Georgia actively promotes freight and logistics issues. In parallel with the state's Transportation Plan, a Statewide Freight Plan 2005-2035 was prepared in 2006-2007 by Cambridge Systematics, which has recently updated it (GDOT, 2011). The new plan will "ensure that Georgia's transportation system is in balance with the demand for freight and logistics." In the South Carolina Multimodal Transportation Plan of 2008, a short chapter on freight movement identifies congestion as a major issue that increases the cost of goods. Port issues are also highlighted. North Carolina has a rail program and is funding track construction and maintenance in order to improve access to rail freight services for new industries. A Statewide Logistics Plan was coordinated starting in 2007 and a Governor's logistics task force was created two years later.

When discussing freight issues, few of the states mention other PAM states and prefer to emphasize their own freight assets (for example, Alabama is "ideally located for trade and business" thanks to its "network of highways, ports, rivers, railroads and airports" serving the main destinations in the country). Two mentions of other states have been identified: a primary goal of the North Carolina's Logistics Plan is to review best practices in order to identify "successful logistics plans in other states and countries to help determine what might work in NC;" and the South Carolina transportation plan commits the state to work with Georgia to develop a plan for a port terminal in Jasper County.

The Jasper County port project deserves fuller treatment as it exemplifies the inherent difficulties in coordinating inter-state freight planning operations. A bi-state port had long been projected on the South Carolina side of the Savannah river, aiming to avoid costly double state investments and contribute to the area's economic growth. The two governors agreed, in 2008, on a joint ownership and development plan. But at the end of 2011, the South Carolina State Ports Authority (SPA), supported by many South Carolina legislators, stopped

\footnotetext{
${ }^{17}$ CAMPO: Capital Area Metropolitan Planning Organization.

${ }^{18}$ DCHC: Durham-Chapel Hill-Carrboro Metropolitan Planning Organization.

${ }^{19}$ BCDCOG: Berkeley-Charleston-Dorchester Council of Governments.

${ }^{20}$ ARC: Atlanta Regional Commission.
} 
further funding for the project. SPA's worry was that the on-going deepening of the Savannah harbor on the Georgia side would disadvantage the Jasper project and other South Carolina ports. Deepening the river to enable the port of Savannah to better accommodate large container ships (expected when the enlarged Panama Canal opens in 2014 or 2015) is one of Georgia's main freight projects. It is also one of PAM's most important freight ventures, but it is not readily perceived as such by other states. What the case really reveals is a problem of trust between the two states: ${ }^{21}$ "We've been out-negotiated (...). Do I think they [Georgia] are sincere in ever building a port in Jasper? No" (AJC, 2011). This statement from the SPA Chairman shows how far the region is from looking at issues in a multi-state coordinated manner.

Finally, it is surprising that the expansion of the Panama Canal, which may change maritime routes and increase the number of maritime containers arriving at East Coast ports, is not significantly discussed in state transportation plans. We saw from the Jasper County port project case how much the new Panama Canal already changes the conditions for freight planning in the PAM region.

\section{CONCLUSION}

This paper examined the spatial patterns of freight and logistics activities and the planning and policy issues associated with them, using Atlanta and the Piedmont Atlantic Megaregion as a case study. Two important aspects of the geography of the logistics industry were discussed: "logistics sprawl" - the spatial deconcentration of logistics facilities and distribution centers in the Atlanta metropolitan area; and the polarization of logistics activities - the concentration of logistics activities in the urban areas of Piedmont Atlantic. The research also shows that local governments give explicit consideration to logistics activities, either for the jobs and tax revenues they can generate, or their adverse impacts on communities. However, we identified a lack of collaboration and agreement between cities and counties regarding zoning and the location of industrial and logistics hubs, and the absence of a regional approach.

The present piece-meal approach to logistics planning should be abandoned. Greater coordination would foster the development of a common approach to logistics enabling planning and zoning done at the various local and regional policy scales to be more consistent. Joint decision-making regarding industrial locations and support for critical logistics networks might include revenue-sharing with coordinated approval of site locations and shared provision of infrastructure. A primary benefit would be a region-wide approach to infrastructure and logistics planning with the resulting benefit of more coherent ranking and selection of freight projects, and a more comprehensive approach to congestion mitigation resulting in improved freight and commodity movement.

The increasing demand for just-in-time delivery and the continual optimization of warehouse inventories mean that efficient distribution networks and optimal siting and sizing of warehouse and distribution centers confer a competitive advantage. In the future, metropolitan areas and states will be increasingly called upon to help provide appropriate conditions for efficient supply chain and logistics activities. The public and private sectors both need to optimize warehouse locations and distribution networks and improve transportation system performance. Both must give explicit consideration to the environmental impacts and quality-of-life concerns frequently reported by the communities

\footnotetext{
${ }^{21}$ Even though South Carolina governor herself does not support SPA's decision to withdraw from the Jasper Port project.
} 
most directly affected by the location and operation of these supply chains. Freight and logistics planning must therefore become a more usual part of planning for metropolitan areas, counties, and cities. Coordinating approaches also is necessary due to tight public budgets.

At the local level, better freight facility management includes proper warehouse siting and accessibility, adequate infrastructure and the consideration of construction, operation and maintenance costs. An important issue is the local employment base, as well as training programs locally or regionally available for warehousing jobs.

At the metropolitan level, the federal government requires all metropolitan areas with populations in excess of 50,000 to prepare comprehensive transportation plans. Local leaders and decision-makers must insist that the transportation planning process takes account of detailed studies of freight and commodity movement and supply chain operations. The inclusion of freight planning would allow geographic areas to examine economies of scale and strategies for increasing the efficiency of logistics and supply chains through better coordination of infrastructure planning and land use decisions.

Finally, freight transportation policy would benefit if the policies of metropolitan areas were coordinated at the megaregional scale, while today most land use planning, transportation planning, and investment processes are organized at local or metropolitan area scales $^{22}$ (Ross and Woo, 2009). The region has become an increasingly important unit for planning in the global economy. Megaregions that connect metropolitan centers spatially and functionally provide an opportunity to achieve much greater efficiency and economies of scale through greater coordination and joint infrastructure planning across cities, regions, and states. It is our belief that freight and logistics planning within the megaregion is appropriate for meeting the challenges inherent in today's economy.

\section{REFERENCES}

Andreoli, D., Goodchild, A. and Vitasek, K. (2010) The rise of mega distribution centers and the impact on logistical incertainty, The International Journal of Transportation Research, 2: 75-88.

AJC (Atlanta Journal Constitution) (2011) South Carolina panel halts new spending for Jasper port, December 20, 2011.

ARC (Atlanta Regional Commission) (2008) Atlanta Regional Freight Mobility Plan, Final Report, February. http://documents.atlantaregional.com/transportation/freight/Freight_Mobility_Plan_Final_Rep ort_Feb\%206_\%202008.pdf (last accessed on April 26, 2012).

ARC (Atlanta Regional Commission) (2010) Cities \& Towns, 2010 Yearbook of Growth and Change. http://documents.atlantaregional.com/infocenter/Cities_And_Towns_Report_2010.pdf (last accessed on April 26, 2012).

Bowen, J. (2008) Moving places: the geography of warehousing in the US. Journal of Transport Geography, 16(6): 379-387.

\footnotetext{
${ }^{22}$ With the exception of initiatives such as federal corridors of national significance, or multi-state corridor coalitions, which do not look, however, at issues such as the siting of warehouses.
} 
Chinitz, B. (1960) Freight and the metropolis, Cambridge: Harvard University Press.

Christopherson, S. and Belzer, M. (2009) The next Move: Metropolitan Regions and the Transformation of the Freight Transport and Distribution System, pp. 194-222 in Pindus, N.; H. Wial and H. Wolman (Ed.) Urban and Regional Policy and its Effects, 2, Washington, DC: Brookings.

Cidell, J. (2011) Distribution Centers among the Rooftops: The Global Logistics Network Meets the Suburban Spatial Imaginary, International Journal of Urban and Regional Research, 35 (4): 832-851.

Cidell, J. (2010) Concentration and decentralisation: the new geography of freight distribution in US metropolitan areas, Journal of Transport Geography, 18(3): 363-371.

Dablanc, L. and D. Rakotonarivo (2010) The impacts of logistic sprawl: how does the location of parcel transport terminals affect the energy efficiency of goods' movements in Paris and what can we do about it? Procedia - Social and Behavioral Sciences, The Sixth International Conference on City Logistics, Edited by E. Taniguchi and R. G. Thompson, 2 (3): 6087-6096.

EEOC (Equal Employment Opportunity Commission) (2004) Retail distribution centers: how new business processes impact minority labor markets. 32p. Available at www.eeoc.gov/eeoc/statistics/reports/retaildistribution/retaildistribution.pdf (last accessed on February 22, 2011).

Foster, T. (2003) The Walgreens Prescription for DC Site Selection, Global Logistics \& Supply-Chain Strategies November: 1(4).

GDOT (Georgia Department of Transportation) (2011) Georgia Statewide Freight \& $\begin{array}{lll}\text { Logistics plan 2010-2050. December. } & \text {. }\end{array}$ http://www.dot.state.ga.us/informationcenter/programs/georgiafreight/logisticsplan/Pages/def ault.aspx (last accessed on April 26, 2012).

Gifford, J., Chen, Z., Li, J., Kelekar, U., Zebrowski, N., Zhou, X. (2011) Mega-regions and freight: evidence from the commodity flow survey and freight analysis framework, Presented at the 90th Transportation Research Board Annual Meeting, Washington D.C, January. http://amonline.trb.org/12ku4n/2 (last accessed on April 26, 2012).

Gilli, F. (2009) Sprawl or Reagglomeration? The Dynamics of Employment Deconcentration and Industrial Transformation in Greater Paris, Urban Studies, 46(7): 1385-1420.

Glaeser, E. and Kohlhase, J. (2004) Cities, regions and the decline of transport costs. Papers in Regional Science, 83: 197-228.

Hall, P., Hesse, M. and Rodrigue, J.P. (2006) Reexploring the interface between economic and transport geography. Guest editorial. Environment and Planning A, 38: 1401-1408.

Hesse, M. (2004) Land for logistics: locational dynamics, real estate markets and political regulation of regional distribution complexes, Tijdschrift voor Economische en Sociale Geographie, 95(2): 162-173. 
Hesse, M. (2002) Changes in Goods Distribution and the City: Physical Distribution as an Indicator of Urban and Regional Development. In Davies, W. and Townshend, I. (Eds) Monitoring Cities: International Perspectives. Calgary and Berlin: International Geographical Union, Urban Commission. ISBN: 0-88953-259-1.

Hesse, M. and Rodrigue, J.P. (2004) The transport geography of logistics and freight distribution. Journal of Transport Geography, 12(3): 171-184.

Isard, W. (1982) Methods of Regional Analysis: an Introduction to Regional Science, Regional Science Reprints \#3, Program in Urban and Regional Studies, Ithaca: Cornell University.

Matthews, J. (2006) Inventory Taxes, Policy Brief, 136, Fiscal Research Center, Georgia State University: $1-4$.

Morlok, E. (1988) Freight Transportation Planning and Logistics, in Bianco, L. and La Bella, A. (Eds) Freight transport planning and logistics: proceedings of the International Seminar on Freight Transport Planning and Logistics held in Bressanone, Italy, July.

Movahedi B., Lavassani, K. and Kumar, V. (2009) Transition to B2B e-Marketplace Enabled Supply Chain: Readiness Assessment and Success Factors, The International Journal of Technology, Knowledge and Society, 5 (3): 75-88.

O'Connor, K. (2010) Global city regions and the location of logistics activity, Journal of Transport Geography, 18(3): 354-362.

Pertierra, B. (2010) Supply chain and logistics, drivers of economic development, presentation at Metro Atlanta Chamber of Commerce, November 16. Courtesy of the author.

Rodrigue, J.P. (2004) Freight, gateways and mega-urban regions: The logistical integration of the BostWash corridor, Tijdschrift voor economische en sociale geografie, 95(2): 147-161.

Ross, C. (Ed.) (2009) Megaregions, Planning for Global Competitiveness, Washington, DC: Island Press.

Ross, C. and Woo, M. (2010) A Matter of Scale: Megaregions and High Speed Rail. Presentation at Associations of Collegiate Schools of Planning Conference, Minneapolis, October 6-10.

Ross, C. and Woo, M. (2009) Identifying Megaregions in the United States, Implications for Infrastructure Investment, in Ross, C. (Ed.) Megaregions, Planning for Global Competitiveness, Washington, DC: Island Press: 53-80.

Ross, C., Barringer, J. and Amekudzi, A. (2009) Mobility in the Megaregion, in Ross, C. (Ed.) Megaregions, Planning for Global Competitiveness, Washington, DC: Island Press: 140-165.

Savy, M. (2006) Logistique et territoire, Paris: La Documentation française.

Woudsma, C., Jensen, J., Kanaroglou, P., Maoh, H. (2008) Logistics land use and the city: A spatial-temporal modeling approach, Transportation Research Part E: Logistics and Transport Review, 44(2): 277-297. 